\title{
WEAK INSTITUTIONS AND POOR GOVERNANCE IN NIGERIA: A SOCIO- LEGAL PERSPECTIVE
}

\section{Chukwubuikem J.S. Azoro', Chinedu A. Onah ${ }^{2}$ and Queen O. Agulefo ${ }^{3}$}

${ }^{1}$ LL.B, LL.M, B.L, affiliate of the Faculty of Law, Nnamdi Azikiwe University, Awka, Anambra State, Nigeria and Associate Partner at IUC Global Chambers, Awka, Nigeria; Phone Number: +234(0)8061116935; Email: cjsazoro@yahoo.com.

${ }^{2}$ LL.B, LL.M, B.L, Lecturer and PhD Candidate at the Faculty of Law, Nnamdi Azikiwe University, Awka, Anambra State; +234(0)8064794333; Email: ca.onah@ unizik.edu.ng, edutony90@yahoo.com

${ }^{3}$ LL.B, B.L, Legal Officer, Nnamdi Azikiwe University, Awka, Anambra State, Nigeria and LL.M Candidate at the Faculty of Law, Chukwuemeka Odumegwu Ojukwu University, Igbariam Campus; Phone Number: +234(0)8037773668; Email: qo.agulefo@ unizik.edu.ng.

Cite this article:

Azoro C.J.S. , Onah C.A., Agulefo Q.O. (2021), Weak Institutions and Poor Governance in Nigeria: A Socio-Legal Perspective. African Journal of Law, Political Research and Administration 4(2), 61-70. DOI: $10.52589 / A J L P R A-$ 5IUFPPRU

\section{Manuscript History}

Received: 16 Nov 2021

Accepted: 29 Nov 2021

Published: 4 Dec 2021

Copyright $\odot 2020$ The Author(s). This is an Open Access article distributed under the terms of Creative Commons Attribution-NonCommercialNoDerivatives 4.0 International (CC BY-NC-ND 4.0), which permits anyone to share, use, reproduce and redistribute in any medium, provided the original author and source are credited.
ABSTRACT: The Nigerian state as a governance template has been dominated by the vexatious problem of underdevelopment since post-colonial history. Good governance and development as an intertwine concept have largely been elusive, rather, poor governance has dominated the Nigerian society, resulting from leadership problems, pervasive corruption, the existence of multiple centres of loyalty base regime, ethnic and religious interest among others, all indicative of weak, underperforming or non-performing institutions of government. This paper made an in-depth inquiry into the correlation between weak institutions and poor governance, highlighting the Nigerian situation. It critically analyzed the concept of good governance as the opposite of poor governance. This paper found that unless the Nigerian state cures itself of the malaise of weak institutions and procures a situation where both the leaders and the led imbibe the ethos of good governance, it will continue to struggle with the burden of poor governance and the concomitant lack of social development it breeds in the society.

KEYWORDS: Poor Governance, Weak Institutions, Leadership, Development, Nigeria. 


\section{INTRODUCTION}

The concept of good governance has become one of the most determinants for evaluating the performance of governments in the modern world. ${ }^{1}$ The failure of a country to meet up to the qualifying criteria of good governance results in a judgment that there is poor governance. ${ }^{2}$ The presence of widespread systemic corruption and large scale insecurity of lives and property is indicative of weak, underperforming or non-performing institutions, and correlatively, may be classified as a manifestation of poor governance.

Emerging trends point to good governance as a panacea towards accelerated development in the economic, political and social sectors of nations. As such, states (Nigeria inclusive), wishing to realize, promote or maintain economic, political and social strides, should strive to embrace good governance. ${ }^{3}$ Highly developed nations can attest to the promotion of national development through the application of good governance in their development administration. ${ }^{4}$

Efficient institutions promote social order, and can only be procured when both the leaders and the ones being led embrace the good governance philosophy. This is because both the leaders and the led have their (individual) roles to play in order to promote strong, viable and efficient institutions. ${ }^{5}$ By so doing, the society would have embraced good governance which in turn will promote the society's development.

\section{Weak Institutions: The Nigerian Situation}

A weak institution depicted a state of decline or powerlessness of government agencies to effectively discharge some of the fundamental responsibilities of the state such as the maintenance of law and order and the protection of its territorial integrity. ${ }^{6}$ Some of the manifestations of institutional weakness are losing control of territory or the sole power of using physical force therein, the crisis of legitimacy in which some part of the state seeks disintegration, inability to provide basic services to the citizens etc. ${ }^{7}$

In a culturally plural and religiously balkanized society like Nigeria, the basic yardstick for measuring the effectiveness of the government lies in its capability to develop an institutional framework that can facilitate the harmonious existence of the citizens through the integrative process of representative governance, sound judicial system and effective law enforcement agency. However, the Nigerian government was established on a fragile legitimacy, by the diarchic British colonial administrative system under which existed a relatively weak central authority with more autonomous regions in terms of administration which invariably confer on the independent Nigerian state. The colonial legacy of relatively strong regional and local ethnic authorities and weak central institutions in which the institutional mechanism for central

\footnotetext{
${ }^{1}$ MO Oseghale, 'The Challenges of Governance and Corruption on Development and Rule of Law in Nigeria', (2020) 8(1) Journal of Law and Criminal Justice, 88 - 100, 88.

${ }^{2}$ Ibid.

${ }^{3}$ CC Onichakwe, 'The Role of Good Governance and Development Administration in National Development', (2016)11 International Journal of Development and Management Review (INJODEMAR), 176 - 186, 176. ${ }^{4}$ Ibid.

5 JA Ilepe, 'Good Governance and Development in Nigeria: The Gap between Rhetoric and Reality', (2017) 7(9) International Journal of Academic Research in Business and Social Sciences, 521 - 531, 521.

${ }^{6}$ A Usman, AR Romle \& A Bashir, 'Institutional Weakness and Conflict Management in Nigeria: the need for Collaborative Governance', (2015) 1(11) Aust. J. Basic \& Appl. Sci., 1 - 7, 1. ${ }^{7}$ Ibid.
} 
coordination are either not fully internalized or weakly internalized, hence, the Nigerian central authority appear grossly infective to exercise substantial control over the entire geographical enclaves which, therefore, paved the way for the perpetuation of violence and conflicts. ${ }^{8}$ Put differently, the contemporary Nigerian state has some of the regular attributes of institutional weakness such as central government incapacitation that it has minimal practical control over a lot of its territory; non-procurement of basic service; pervasive incidence of corruption and criminality; displacement of citizens due to crisis and threat of secession as well as a sharp economic decline.

Thus, the Nigeria state as it is constituted today depicts a picture typical of a failed state in terms of its institutional framework and central regulative capacity. ${ }^{9}$ For example, despite over five decades of political independence, the country is still tinkering here and there in search of legitimacy and loyalty from its citizens amidst serious threats of secessionism, separatism and insurgency. ${ }^{10}$ Political conflict has therefore become a recurrent decimal in the Nigerian state which in several instances transform into violent confrontation either among the citizens or between the citizens and the government. Though politics as conceptualized by scholars is a conflict generating process, as it involves how values are authoritatively allocated among competing groups in the society, hence, political conflicts are inevitable in human society especially in a heterogeneous and plural state like Nigeria. ${ }^{11}$ However, conflicts become problematic when the institutional mechanisms established by the state fail to prevent the escalation of a simple conflict into violence as in the Nigerian case. For instance, a political crisis such as the civil war in the 1970 and the several incidences of inter-ethnic and religious clashes as well the proliferation of ethnic militias and terrorist organizations such as Afenifere, ACF, Odua People Congress, MASSOB, MOSOP, IPOB and Boko Haram, were all anchored on the inability of the Nigerian central government to respond appropriately to issues that mostly serve as the sources of grievances which eventually lead to either the eruption of violence or the emergences of militants.

The existence of structurally weak institutions of governance in a country like Nigeria where it has been very difficult to translate the national economic potentials to realistic sustainable development raises troubling concerns. ${ }^{12}$ These institutions are unable to adequately and effectively perform the functions of governance due to structural logs in administration which pose serious impediments in the discharge of their responsibilities.

\section{Poor Governance in Nigeria}

It is generally agreed that the term 'poor governance' is not readily susceptible to any generally accepted definition, such that scholars approach the subject from a descriptive as opposed to a

\footnotetext{
${ }^{8}$ Ibid.

${ }^{9}$ FC Onuoha, 'Nigeria's Vulnerability to Terrorism: The Imperative of a Counter Religious Extremism and Terrorisms Strategy', (2011) 2(1) African Journal, 89 - 121.

${ }^{10}$ T Falola, Colonialism and Violence in Nigeria (Bloomington: Indiana University Press, 2009), cited in A Usman, AR Romle \& A Bashir, op. cit, p. 1.

${ }^{11}$ JN Hill, Nigeria since Independence: Forever Fragile? (New York: Palgrave Macmillan, 2012), cited in A Usman, AR Romle \& A Bashir, op. cit, p. 1.

${ }^{12}$ OG Owogbemi, 'Anti-Graft Policy of the Federal Government of Nigeria: The Case of Economic and Financial Crimes Commission (EFCC)’, (2012) 6(2) African journal of stability and development, 111 134.
} 
definitive perspective. ${ }^{13}$ Viewed from the descriptive prism, 'poor governance' draws heavily from the concept of 'governance' and is readily accepted to be the opposite of 'good governance'. ${ }^{14}$

Even attempts to come up with a comprehensive meaning of the term 'governance' has generated controversy among experts and scholars, particularly on the practical aspect of the term. However, it has been widely agreed to be "the management of society by the people, or as the exercise of authority to manage a country's affairs and resources". ${ }^{15}$ The term governance is a process of decision making and the process by which decisions are implemented. When decisions are made and implemented, regards being had to participatory nature of that decision, it is good governance. ${ }^{16}$ Likewise, when that decision is consensus-oriented, responsive, effective and efficient, equitable and inclusive and follows the rule of law, that is bound to be good governance. ${ }^{17}$

The 'Institute on Governance' ${ }^{18}$ has expressed the view that the need for governance exists anytime a group of people come together to accomplish an end. It also opined that most given definitions of 'governance', rest on three dimensions, i.e. authority, decision-making and accountability. ${ }^{19}$ It, therefore, came out with its own working definition of governance which is expressed as follows:

Governance determines who has power, who makes decisions, how other players make their voice heard and how the account is rendered. ${ }^{20}$ Governance is therefore a process of directing the affairs of a given nation or organization under whatsoever type of system is adopted with the intent of creating and sustaining orderliness, peace and promoting the general wellbeing of the people of such an organization. ${ }^{21}$

According to Henwood, good governance should possess the following characteristics: (a) prevent the occurrence of tyranny, anarchy, corruption, instability, paralysis, uninformed decision making, unaccountability and unjustified secrecy; (b) result in good, stable and accountable government stemming from effective prevention of negative political trials. ${ }^{22}$ Kate also is of the idea that good governance should be characterized by a predictable, open and enlightened public policy with a bureaucracy that is involved with professional ethos acting in

\footnotetext{
${ }^{13}$ M Nabiebu \& MT Otu, 'Administrative Law and the Challenges of Good Governance in Nigeria under Democratic System of Government: The Exigency of Legal Reforms', (2019) 16(1) Frontiers of Finance and Economics, 15 - 36, 17.

${ }^{15}$ UE Simonis (ed), Defining Good Governance - Conceptual Competition is on (Berlin: Open Access Repository, 2004) cited in JI Mukhtar et al, 'Bad Governance and Insecurity in Nigeria', (2017) 2(1) International Journal of Trend in Scientific Research and Development (IJTSRD), 349 - 355, 349.

${ }^{16}$ P Chinyere, 'The Challenges of Good Governance in Nigeria under Democratic System of Government: An Appraisal', (2013)5 Ekiti State University, Ado-Ekiti Law Journal, p. 147.

${ }^{17}$ See 'Governance', available at $<$ http//www.unescap.org/huset/gg/governance.htm>, cited in M Nabiebu \& MT Otu, op. cit, p. 17.

${ }^{18}$ An independent, Canada-based, not-for-profit public interest institution with its head office in Ottawa.

${ }^{19}$ See Institute on Governance, 'Defining Governance', available at $<$ iog.ca/defining-governance $>$, cited in $\mathrm{M}$ Nabiebu \& MT Otu, op. cit, p. 17.

${ }^{20}$ Ibid.

${ }^{21}$ SO Iroye, 'Nigeria in the Centenary: The Challenges of Governance and Exigency of Legal Reforms', (2014)1 NOUN Journal of Legal Studies, p. 157.

${ }^{22}$ R Henwood, Good Governance and the Public System (Pretoria: University of Pretoria Press, 2001) p. 4.
} 
furtherance of the public good, the rule of law, transparent processes and a strong civil society participating in public affairs. ${ }^{23}$ It is in apparent concurrence with this position that the Nigerian Constitution declared that it, i.e. the constitution, was made for the purpose of promoting good governance and the welfare of all persons. ${ }^{24}$

Having noted the fact that 'poor governance' is the opposite of 'good governance, it follows that the concept of 'poor governance' may be described as any system of governance that lacks the essential characteristics of 'good governance' as identified by Henwood and also by Kate. Whereas good governance signifies a participative manner of governing that functions in a responsible, accountable and transparent manner based on the principles of efficiency, legitimacy and consensus for the purpose of promoting the rights of individual citizens and the public interest, thus indicating the exercise of political will for ensuring the material welfare of society and sustainable development with social justice; poor governance, on the other hand, "signifies the failure to govern competently, effectively and proficiently. ${ }^{25}$ Any leadership that is devoid of transparency, accountability, credibility, justice, selflessness, and fair play is bad. The case of Military Governor of Lagos State \& 2 Ors. v. Chief Emeka Odumegwu Ojukwu \& Anor ${ }^{26}$ provides a ready example of poor governance on the part of the government. In that case, the Lagos State government took over the property of the respondent while totally disregarding the pending litigation over the said property. Luckily, the courts came to the rescue when the supreme court, per Obaseki, JSC, held thus:

In the area where the rule of law operates, the rule of self-help by force is abandoned. Nigeria, being one of the countries in the world which proclaim loudly to follow the rule of law, there is no room for the rule of self-help by force to operate. Once a dispute has arisen between a person and the government or authority and the dispute has been brought before the court, thereby invoking the judicial powers of the state, it is the duty of the government to allow the legal and judicial process to run its full course. The action the Lagos State Government took can have no other interpretation than the show of the intention to preempt the decision of the court. The courts expect the utmost respect of the law from the government itself which rules by the law.

In the developmental aspect, also, governing without transformative capacity is bad governance. In view of this, Sobhan argued thus:

The basic argument about the role of governance in development holds that weak governance originates due to a sequential failure of the state to (a) project a developmental vision; (b) demonstrate a commitment to realize this vision, through putting in place policies and programs, as well as calibrating its allocative priorities to realize this vision; (c) develop a capacity to fulfil its commitments. This includes administrative and technical capacity as well as the political capacity to mobilize necessary

\footnotetext{
${ }^{23}$ YM Yusuf, 'Democracy as a Cornerstone for Good Governance and Rule of Law', (2002)5 University of Maiduguri Law Journal, cited in M Nabiebu \& MT Otu, op. cit, p. 18.

${ }^{24}$ Preamble to the 1999 Constitution of the Federal Republic of Nigeria (as amended 2018).

25 JI Mukhtar et al, op. cit, $349-355,350$.

${ }^{26}$ (1986)1 NWLR (pt. 18) 621 at 636, paragraphs B - D.
} 
support both within civil society as well as in the political arena to translate the vision into reality. ${ }^{27}$

Poor governance and bad governance are nominally used interchangeably to depict the unfavourable relationship between those who govern and those who are governed as a consequence of decision-making. This unfavourable relationship is created as a consequence of external factors or decisions such as violation of central or acceptable norms, such as those of liberal democracy and bad economic policy. Poor governance collectively encompasses governance in government and corporate settings and touches a variety of situations from corruption, deceit and to the passing of unfair policy. ${ }^{28}$

Nigeria's crisis of governance is quite conspicuous. Ruling elites and public institutions have not provided essential collective goods, such as physical infrastructure, the rule of law, or legitimate symbols of state authority and political community. Poor governance appears to be endemic in the Nigerian state; good governance has proven elusive if not chimerical, as cycles of civilian and military government have been punctuated by false starts, failed transitions, and recurring challenges to the stable rule. ${ }^{29}$ Elected regimes have faltered over precarious institutions, factionalism among elites, and pervasive corruption. The First Republic, a parliamentary system put in place by the departing British colonists, suffered from an institutional design that encouraged ethnic segmentation and invidious regional competition for power. The regime quickly succumbed to communal polarization, political conflict, and social strife. The military stepped into the maelstrom with a coup in 1966. But the officers were themselves vulnerable to ethnic antagonism, leading to a countercoup and the ensuing civil war. Over the next thirteen years, there was a succession of "corrective" military regimes, promising a return to democracy but deferring political reform until 1979, when General Olusegun Obasanjo handed power back to the civilians. ${ }^{30}$ The Second Republic, a presidential regime modelled on the American system, fared worse than its predecessor, lasting merely four years. Massive corruption, mismanagement, political chicanery, and epidemic violence quickly eroded the regime's ability to govern and undermined the legitimacy of the democratic system in the eyes of the public. Once again, the armed forces stepped in with promises of remedial action. ${ }^{31}$

Despite their reformist pretensions, military regimes have proven no more capable than the civilians at resolving central challenges of state-building and development. The turbulent military interventions of 1966 yielded nearly a decade of rule by General Yakubu Gowon, who prosecuted the civil war, sought to address problems of national unity, and presided over the early years of the petroleum boom. His dilatory response to pressures for democratization, and mounting evidence of corruption amid the oil windfall, prompted further intervention by senior

\footnotetext{
${ }^{27}$ R Sobhan, 'How Bad Governance Impedes Poverty Alleviation in Bangladesh', Working Paper No. 147, Research Program on Good Governance and Poverty Alleviation, OECD Development Center, p. 13.

${ }^{28}$ MO Oseghale, op. cit, pp. 89 - 90. Also see N Tijani \& VB Ashi, 'The Judiciary and the Challenges of Good Governance in Nigeria: an Evaluation', (2008)1 Journal of Private \& Commercial Law, p. 113.

${ }^{29}$ L Diamond, 'Nigeria: The Uncivic Society and the Descent into Praetorianism', in L Diamond, et al (eds), Politics in Developing Countries: Comparing Experiences with Democracy $\left(2^{\text {nd }}\right.$ edn, Boulder: Lynne Rienner, 1995).

${ }^{30}$ PM Lewis, 'The Dysfunctional State of Nigeria', in N Birdsall, M Vaishnav \& R Ayres (eds), Short of the Goal: U.S. Policy and Poorly Performing States (Washington DC: Center for Global Development, 2006) ${ }^{31}$ Ibid. pp. $83-116,89$.
} 
officers. General Murtala Muhammad replaced Gowon in July 1975, promising rapid movement toward a transition to civilian rule, greater economic probity, and administrative reform. Only six months later, Murtala was assassinated in a failed coup attempt and was replaced by his second in command, Olusegun Obasanjo, who continued the regime's programs. Apart from overseeing the transition to civilian rule, the Murtala-Obasanjo government advanced an ambitious program of state-led industrialization and expansive social provision. ${ }^{32}$

The four-year civilian interregnum was terminated in 1983 by General Muhammadu Buhari, amid popular hopes that his regime would overhaul the corrupt shambles left by the Second Republic. In the event, Buhari's regime instigated a new era of military dominance that proved more corrosive to state capabilities, economic development, and social stability than its predecessors. The tenures of Buhari (1983-85), Ibrahim Babangida (1985-93), and Sani Abacha (1993-98) traced a downward spiral of repression, arbitrary rule, economic predation, and the erosion of such central institutions as the military, the central bureaucracy, major services, and infrastructure. ${ }^{33}$

With the ouster of the regime of General Buhari (and his close associate General Tunde Idiagbon), whose autocratic style and economic ineptitude dissipated popular support, General Babangida pledged essential political and economic change, delivering a schedule for transition to democratic rule along with a program to stabilize the economy. The reformist impulse was fleeting, however, as Babangida repeatedly postponed and amended the political program, wavered on economic reform, and soon jettisoned even the pretence of stable management. The general employed coercion to quell opposition, while his regime was shadowed by evidence of prodigious corruption. The nadir of Babangida's rule was his abrogation of the democratic transition in June 1993, when he annulled the results of a presidential election that had been widely regarded as fair by a nation anxious to return to civilian rule. ${ }^{34}$ The ensuing crisis provoked widespread uncertainty, ethnoregional antipathy, and further economic decline. Babangida was induced to depart, leaving a flimsy civilian caretaker committee in his wake, which was scrapped in a matter of weeks by the defence minister, General Sani Abacha. ${ }^{35}$

Abacha, with none of the finesse or political alacrity of his predecessor, displayed an even more dictatorial and venal style of rule. He wielded the state security apparatus to intimidate, harass, jail, or murder political opponents and contrived a political "transition" that would perpetuate his own rule as a civilian president. After briefly tinkering with populist economic policies, the regime returned to a semblance of orthodox measures, but fiscal indiscipline and unalloyed economic predation left the economy in the doldrums. Abacha is estimated to have amassed a fortune of perhaps US\$6 billion 90 in a mere four and a half years, largely embezzled from the public treasury or diverted from state-owned enterprises and projects. The speed and magnitude of plunder at the centre was mirrored by the accelerated decline of the education and health systems, public administration, utilities, and domestic fuel supplies. Social and political tensions intensified as the general's "self-succession" seemed imminent. Abacha's

\footnotetext{
${ }^{32}$ Ibid, pp. $89-90$.

${ }^{33}$ Ibid.

${ }^{34}$ PM Lewis, 'Endgame in Nigeria? The Politics of a Failed Democratic Transition,' (1994)7 African Affairs, 93.

${ }^{35}$ PM Lewis, 'The Dysfunctional State of Nigeria', op. cit, p. 90.
} 
unexpected death in June 1998, officially attributed to a heart attack, opened the way for reformers in the military to pursue political change. General Abdulsalami Abubakar, selected by the ruling military council, elaborated a program to return Nigeria to civilian rule. The regime adhered to its expeditious schedule of transition, transferring power to an elected civilian regime in May 1999. The newly elected president was Olusegun Obasanjo, the retired general who had handed power to the politicians of the Second Republic two decades earlier. ${ }^{36}$

The resumption of civilian rule has brought many improvements in the climate of popular participation and human rights in Nigeria. In other areas of governance, the changes have been less favourable. The regime is burdened by the accumulated depredations of preceding rulers, manifesting in a depleted treasury, a huge debt overhang, dilapidated public institutions, endemic corruption, and simmering social antagonism. The first presidential term has seen little progress on the chronic problems of the economy, while communal violence has exploded in myriad conflicts across the country. A contentious and largely inexperienced political class shows a little capacity to address the country's pressing economic and social challenges. ${ }^{37}$

\section{The Correlative Effect of Weak Institutions on Governance}

Weak institutions characterized by leadership problems, pervasive corruption, ethnic and regional base loyalty and interest, and a general amoral public sphere have all colluded to prevent efficient governance and by extension rapid development ${ }^{38}$ upon which Odione Akharine defined the Nigerian political state as a bizarre, ${ }^{39}$ while Kescelma described it as an unfinished project characterized by instability and uncertainties. ${ }^{40}$ The Nigerian state has also been described as a diabetic patient whose excess sugar in its bloodstream serves no purpose. ${ }^{41}$

According to Amadi, the main reason for the underdevelopment of Nigeria is not unconnected with bad governance, influenced by political jaywalking and legal jiggery-pokery. That is why industries are sited where they should not be; that is why the railway system has retrogressed from what we inherited from Lord Luggard since 1914; that is why the roads remain underdeveloped, and those developed remains unmaintained; that is why the aviation industry remains an unserious business, monopolized by few airlines; that is why the waterways are undeveloped and unnavigable; that is why the sports industry remains untapped and our citizens spend time and money on foreign sports; that is why our tourism industry repel tourists. Similar lamentations are generated by the less than satisfactory development of our agricultural, educational and health industries. ${ }^{42}$

Successive regimes of Nigerian leaders merely pay lip service to the twin concepts of good governance and development. They only mouth ideas to gain access to political power and

${ }^{36} \mathrm{Ibid}$, pp. $90-91$.

${ }^{37} \mathrm{Ibid}$.

${ }^{38}$ See Attorney-General of Ondo State v. Attorney-General of the Federation \& 35 Ors (2002)14 WRN 1 and Olafisoye v. FRN (2005)51 WRN 52 which are Supreme Court decisions highlighting the negative effects of corruption on the society.

${ }^{39}$ A Odion, 'Human Rights Diplomacy and Democracy in Nigeria', (2007) 6(7) Journal of Constitutional Development, p. 10.

${ }^{40}$ JA Ilepe, op. cit, p. 521.

${ }^{41}$ D Ameh, The Diabetic Nature of the Nigerian State (2007), JA Ilepe, op. cit, p. 521.

${ }^{42}$ GOS Amadi, 'Political Jaywalking and Legal Jiggery-Pokery in the Governance of Nigeria: Wherein Lies the Rule of Law?', Being the Text of an Inaugural Lecture delivered in September, 2015 at the $57^{\text {th }}$ Inaugural Lecture of the University of Nigeria, Nsukka, pp. $108-109$. 
public offices after which they invariably become either too lethargic to walk the talk or are swallowed or arrested by what was now become known as the "system" which is a euphemism for dysfunctional state of affairs of Nigeria's public institutions and the public domain perverted by plebendalism. ${ }^{43}$ The consequence of this poor attitude to governance is fairly well-known. It includes mass poverty, economic stagnation, political instability, corruption, unemployment, insurgency and terrorism, social unrest and conflict, abuse of power and the principle of the rule of law, all of which reinforces one another.

Mass poverty and the wide gap between the few rich and the large poor has been the result of a state with massive potentials but which has ironically experienced a steady decline since oil windfall peaked more than three decades ago. The slow and disarticulated growth in concert with rising population and mass unemployment have deposited dramatic increases in the poverty levels of Nigeria state, thereby causing social and political instability. ${ }^{44}$ Indeed, flagging growth, rising poverty and deep-rooted economic inequality constitute a direct cause of social instability whether ethnic conflicts, religious bigot, or separatist agitation or agenda in Nigeria, the cause can be completely put down to economic decline. The resurfaced and persistent herdsmen/Fulani menace, kidnapping and terrorism could partly be put down to the availability of idle and unemployed youths. The Niger-Delta problem, a resource propelled debate is squarely within the general parameters of deprivation. ${ }^{45}$

However, the most dangerous and negative challenge that has frustrated governance in Nigeria is the widespread problem of endemic corruption. Corruption has become a contagious and alignment socio-economic and political problem enervating the development aspirations of the state. It permeates every stratum of the society, reduces the values system and has been institutionalized. ${ }^{46}$ Even the present government led by President Buhari, which was majorly voted into power in 2015 on anti-corruption slogan is not left out of this endemic virus as evident in some of her top officials being fingered in the act while the president looks the other way round as agitations for their investigations and prosecutions felt into the deaf air of the presidency. ${ }^{47}$

From the foregoing discourse, it is undoubtedly clear that there is a nexus between good governance and development, especially in the context of the nature, logic and character of the Nigerian state. This is largely due to the fact that how fragile, weak, irresponsive, patron-client and dependent a state is going a long way to determining the governance pattern in that state and concomitantly, the state of development of the said state. It will suffice to state here, the words of Mrs Oby Ezekwesili in her keynote address in Portharcout themed "literature and the creative economy". According to her, "Nigeria is perhaps the best-known example of African paradox. It is a country that has struggled with the development process over the last 53 years of her independence as the $6^{\text {th }}$ largest producer of oil in the world; it has earned more than half a trillion dollars in oil export since the discovery of that commodity in the South-South region of the country where we are gathered today. Unfortunately, the massive revenue from oil has been a source of enormous sorrow to citizens due to poor government by our political elite

\footnotetext{
${ }^{43}$ JA Ilepe, op. cit, p. 522.

${ }^{44}$ Ibid.

${ }^{45}$ I Aghedo, 'Saving Peace, Reaping Violence: Understanding the Resurgence of Kidnapping in Post-Amnesty Niger-Delta, Nigeria', (2015) 7(2) Insight on Africa, 137 - 153.

46 JA Ilepe, op. cit, p. 522.

${ }^{47}$ Ibid.
} 
over the many decades since its discoveries". ${ }^{48}$ She went further to say that Nigeria has therefore tragically failed to translate rich resources endowment to improvement in the standard of living of her citizens resulting from bad governance, hence, we today have 69 percent of over 170 million of our citizens in the poverty bracket according to the latest data from the National Bureau of Statistics. ${ }^{49}$ Even though the last one decade has witnessed an increase in our economic growth rate to an average of seven percent per annul regrettably, this has not resulted in poverty reduction, the poor governance or its more virulent manifestation, public corruption is of course the fundamental reason for Nigeria's poor economic performance. She also states that Nigeria's problem is bad governance. ${ }^{50}$

There will be no meaningful governance and development if this crisis is not thoroughly dealt with. As Akindele posited, the crisis runs deep throughout the general facets of Nigeria: election rigging, perversion of ethnicity, insistence on bribes as pre-condition for performing legitimate duties, bureaucratic indulgence in receiving bribes, downright looting of public treasury cum money laundering by the elected and appointed politicians all constitute corruption. $^{51}$

\section{CONCLUSION}

Government as an institution is a process whereby the will of the state is formulated, expressed, and enforced. Therefore, the political will to authoritatively allocate the collective values through the inputs and output mechanism process for the good of the society and in line with the social contract theory must not be compromised. The president as the arrowhead of government in synergy with the legislative and judiciary arms of government are responsible and liable for the provision of good governance that will usher in a sustainable socio-economic and political development and good quality of life of the citizenry. Consequently, the action and inaction, the decision and policies of those who occupy political offices in the various institutions go a long way at determining the fortune of the state or otherwise. The above facts on the theory of leadership to governance underscore the dialectics that characterize the absence of good governance in the Nigerian state. ${ }^{52}$ A fortiori, those occupying leadership positions in the country must embrace the ethos of good governance and eschew corruption, nepotism, fundamentalism, greed, and other vices that characterize poor governance in Nigeria. They must show a persistent drive to positive nation-building through the development of strong institutions of governance. This will surely have a correlative effect on the positive development of the Nigerian state.

The crisis of bad governance in Nigeria is further exacerbated by the fact of the governed continually sleeping on their rights, gnashing their teeth in self-inflicted impotency, wringing their hands in silent despair, and hoping against hope for who would bell the cat. The governed should collectively bell the cat during general elections by appropriately exercising and defending their franchise to vote out bad governance wherever it exists in Nigeria. The truth remains that as the electorate make their bed, so shall they lie on it. ${ }^{53}$

\footnotetext{
${ }^{48}$ O Ezekwesili, 'Bad Governance behind Nigeria's Poverty', (2013), cited in JA Ilepe, op. cit, p. 528.

${ }^{49}$ Ibid.

${ }^{50}$ Ibid.

${ }^{51}$ Ibid, pp. $523-524$.

52 JA Ilepe, op. cit, p. 526.

${ }^{53}$ GOS Amadi, op. cit, p. 153.
} 